\title{
Manajemen Diklat Berjenjang Tingkat Dasar Untuk Meningkatkan Kompetensi Guru Paud (Kegiatan Swadaya Bekerjasama Dengan SKB dan Himpaudi Kecamatan Aikmel)
}

\author{
Oleh: \\ Ittihad \\ Email: ittihad.1977@gmail.com
}

\begin{abstract}
Abstrak: Manajemen pendidikan dan pelatihan (Diklat) Berjenjang oleh Himpaudi Kecamatan Aikmel Kabupaten Lombok Timur untuk Meningkatkan Kompetensi Guru PAUD. Penelitian ini bertujuan untuk mengetahui (1) perencanaan Diklat Berjenjang, (2) pengorganisasian Diklat Berjenjang, (3) pelaksanaan kegiatan Diklat Berjenjang, dan (4) pengawasan dan evaluasi kegiatan Diklat Berjenjang. Penelitian ini menggunakan pendekatan kualitatif dan jenis penelitian studi kasus. Guna memperoleh keabsahan data, peneliti melakukan trianggulasi sumber dan triangulasi teknik. Adapun hasil dari penelitian ini yaitu (1) banyak guru PAUD yang belum memahami metode untuk diterapkan pada anak usia dini; (2) setelah mengikuti Diklat Berjenjang, guru PAUD lebih memahami metode dan pembelajaran yang tepat untuk diterapkan pada anak usia dini; dan (3) kegiatan Diklat Berjenjang menambah wawasan dan pengetahuan guru PAUD.
\end{abstract}

Kata kunci: Manajemen, Diklat Berjenjang, Himpaudi, kompetensi guru PAUD

\section{A. PENDAHULUAN}

Profesionalisme tenaga pendidik merupakan kemampuan seorang pendidik atau yang sering disebut sebagai guru, dalam melakukan tugas pokoknya mulai merencanakan hingga evaluasi pembelajaran. Indikator profesionalisme guru yaitu kompetensi guru, komitmen guru, dan pengem- bangan karier guru. Pada kompetensi guru, terdapat empat kompetensi yang harus dimiliki guru, meliputi: (1) kompetensi pedagogik; (2) kompetensi kepribadian; (3) kompetensi sosial; dan (4) kompetensi profesional. Upaya pencapaian visi dan misi sekolah tidak lepas dari peran sumber daya manusia yang ada di sekolah tersebut. Adapun salah satu kendala dalam upaya mencapaian visi dan misi sekolah yaitu kualifikasi tenaga pendidik yang bukan dari bidang yang dikerjakan. Guna mengatasi persoalan tersebut perlu adanya kegiatan Pendidikan dan Pelatihan (diklat) untuk meningkatkan profesionalisme tenaga pendidik. 
Diklat merupakan salah satu bentuk pengembangan pegawai yang pada akhirnya berdampak pada peningkatan kinerja pegawai. Pada sekolah atau lembaga pendidikan, fungsi diklat sangat penting untuk peningkatan kualitas tenaga pendidik di sekolah tersebut. Menurut Simamora (1997:34) "tujuan pelatihan dan pengembangan, antara lain: (a) memperbaiki kinerja; (b) membantu memecahkan persoalan operasional; (c) mempersiapkan pegawai untuk promosi serta memenuhi kebutuhan pribadi”. Hasil wawancara pendahuluan dengan pengurus PLS Kecamatan Aikmel dan Ketua Himpaudi Kecamatan Aikmel diketahui bahwa masih banyak tenaga pendidik PAUD yang belum sepenuhnya memiliki keterampilan mengajar dan kualifikasi pendidikannya bukan dari PAUD. Untuk itu salah satu upaya meningkatkan profesionalisme tenaga pendidik PAUD yaitu dengan mengadakan kegiatan Diklat Berjenjang.

Diklat ini terbentuk berdasarkan kerjasama antara Himpaudi Kecamatan Aikmel dan PLS Kecamatan Aikmel serta Kepala PAUD Se Kecamatan Aikmel. Hal demikian dilakukan sebagai upaya untuk meningkatkan kualitas dan profesionalisme tenaga pendidik PAUD. Himpaudi merupakan organisasi mitra, adapun mitra Himpaudi yaitu Pemerintah Daerah dan Dinas Pendidikan. Himpaudi Kabupaten Lombok Timur merupakan kepengurusan wilayah tingkat daerah kabupaten. Tujuan didirikannya Himpaudi agar pendidik dan tenaga kependidikan PAUD mempunyai wadah dalam kegiatannya. Terkait diklat yang diselengarakan, Himpaudi adalah salah satu provider yang mendapat rekomendasi dari direktorat P2TK untuk menyelenggarakan Diklat Berjenjang yaitu Diklat Tingkat Dasar, Diklat Tingkat Lanjut, dan Diklat Tingkat Mahir dalam rangka meningkatkan kompetensi mengajar pendidik PAUD.

Dibandingkan dengan organisasi lain, Himpaudi yang lebih aktif bersosialisasi dan intensif dalam melaksanakan kegiatannya yang salah satunya adalah kegiatan Diklat Berjenjang. Jika dibandingkan dengan organisasi lain yang dalam satu tahun organisasi lain hanya menyelengarakan diklat beberapa kali saja, namun Himpaudi dalam satu tahun melaksanakan Diklat Berjenjang hingga puluhan kali. Seperti informasi yang peneliti peroleh dari Johariah, S.Pd selaku ketua panitia pelaksana lebih dari 100 peserta yang mengikuti Diklat Berjenjang tersebut. 
Ittihad | Manajemen Diklat Berjenjang Tingkat Dasar Untuk.Meningkatkan Kompetensi Guru Paud (Kegiatan Swadaya Bekerjasama Dengan SKB dan Himpaudi Kecamatan Aikmel)

\section{B. METODE}

Penelitian ini menggunakan pendekatan kualitatif mendeskripsikan peristiwa dan perilaku orang atau suatu keadaan pada tempat tertentu secara rinci dan mendalam secara naratif. Jenis penelitian ini adalah studi kasus karena menyelidiki secara langsung dengan latar yang alamiah dan memusatkan perhatian pada suatu peristiwa secara intensif dan rinci karena akan mendeskripsikan, membahas dan mengungkap fakta secara mendalam terhadap suatu objek tertentu. Kehadiran peneliti dalam pendekatan kualitatif yaitu sebagai instrumen penelitian yang paling penting di dalam pengumpulan. Penelitian dilakukan di Himpaudi Kecamatan Aikmel yaitu penyelenggara Diklat Berjenjang bagi guru PAUD yang berlokasi di Gedung olahraga Kanit Dikpora Kecamatan Aikmel. Lembaga ini merupakan bagian dari organisasi Himpunan PAUD se Indonesia.

Sumber data dalam penelitian ini diperoleh pada beberapa informan yang berbeda, namun peneliti tetap menentukan informan kunci (key person) dalam penelitiannya melalui beberapa pertimbangan. Informan kunci dalam penelitian ini yaitu pengurus Himpaaudi Kecamatan Akimel dan PLS PAUD Kecamatan Aikmel. Pengumpulan data yang digunakan peneliti terdiri dari observasi, wawancara dan dokumentasi. Analisis Data dalam penelitian ini dilakukan dengan tiga langkah yaitu reduksi data, display data, dan vertifikasi data atau penarikan kesimpulan.

Teknik pengecekan keabsahan data dalam penelitian ini adalah ketekunan pengamatan, triangulasi, dan kecukupan Referensial yaitu menggunakan alat bantu elektronik untuk mendapatkan data dukung. Alat bantu elektronik tersebut berupa alat perekam suara untuk merekam hasil wawancara dan kamera untuk memotret objek penelitian. Prosedur dalam penelitian ini meliputi Tahap persiapan, Tahap pelaksanaan, Tahap Pelaporan.

\section{HASIL}

Saat ini banyak guru PAUD yang belum memahami metode apa yang tepat untuk diterapkan pada anak usia dini, untuk itu perlu adanya suatu wadah untuk mengampung aspirasinya dan tempat berkonsultasi terkait kendala-kendala yang dihadapi guru PAUD. Himpaudi Kecamatan Aikmel yaitu suatu wadah yang menampung berbagai urusan dan kegiatan PAUD di wilayah kecamatan Aikmel. 
Salah satu kegiatannya yaitu penyelenggaraan Diklat Berjenjang bagi guru PAUD dalam upaya meningkatkan kompetensi dan profesionalisme mengajar.

Diklat Berjenjang yang dilaksanakan oleh Himpaudi Kecamatan Aikmel yaitu Diklat Tingkat Dasar, Diklat Tingkat Lanjutan, dan Diklat Tingkat Mahir. Diklat tingkat dasar ditujukan untuk mempersiapkan pendidik sebagai pengasuh dengan kompetensi minimal. Diklat tingkat lanjutan ditujukan untuk mempersiapkan pendidik yang kompeten sebagai guru pendamping. Diklat tingkat mahir ditujukan untuk mempersiapkan guru kompeten sebagai guru PAUD. Program Diklat Berjenjang yang diselenggarakan oleh Himpaudi dapat mengurangi Sistem Kredit Semester (SKS) yang harus ditempuh oleh peserta diklat, apabila peserta tersebut melanjutkan pendidikan Strata 1 (S1) di jurusan PAUD. Hal demikian dapat dilakukan oleh peserta diklat dengan syarat telah menyelesaikan tugas mandiri baik mulai jenjang Diklat Tingkat Dasar, Diklat Tingkat Lanjutan, maupun Diklat Tingkat Mahir.

Penentuan jadwal pelaksanaan Diklat Berjenjang yang diselenggarakan oleh Himpaudi di wilayah Kecamatan Aikmel dilakukan setelah persiapan diklat selesai. Adapun persiapan yang dilakukan yaitu menentukan kepanitiaan kegiatan diklat, lokasi yang akan digunakan sebagai kegiatan diklat, dan lain sebagainya. Jadwal pelaksanaan Diklat Berjenjang ditentukan oleh pengurus Himpaudi di wilayah kecamatan Aikmel yang akan melaksanakan diklat, pengurus Himpaudi kabupaten/kota Lombok Timur, dan pihak Dinas setempat berdasarkan hasil komunikasi dan kesepakatan bersama. Setelah mendapat kesepakatan bersama terkait jadwal pelaksanaan diklat, panitia diklat akan mengumumkan jadwal pelaksanaan Diklat Berjenjang pada peserta diklat yaitu para guru PAUD.

Syarat yang harus dipenuhi oleh peserta diklat terdiri dari syarat umum dan syarat khusus. Syarat umum yaitu peserta yang mengikuti harus sehat jasmani dan rohaninya, kemudian bersedia mengikuti diklat dari awal sampai akhir kegiatan. Sedangkan syarat khusus yaitu pada Diklat Tingkat Dasar usia minimal 17 tahun, berpendidikan SMA atau sederajat, berpengalaman kerja selama 1 tahun (ditujukan dengan SK masih aktif) dan pengalaman mengikuti pelatihan Diutamakan pernah mengikuti pelatihan PAUD. Pada Diklat Tingkat Lanjutan usia minimal 20 tahun berpendidikan SMA atau sederajat, berpengalaman 2 tahun (ditujukan dengan SK masih aktif) dan memiliki sertifikat diklat tingkat dasar. Sedangkan pada Diklat 
Ittihad | Manajemen Diklat Berjenjang Tingkat Dasar Untuk.Meningkatkan Kompetensi Guru Paud (Kegiatan Swadaya Bekerjasama Dengan SKB dan Himpaudi Kecamatan Aikmel)

Tingkat Mahir usia minimal 23 tahun berpendidikan diprioritaskan S1/D IV berpengalaman 3 tahun (ditujukan dengan SK masih aktif) dan memiliki sertifikat diklat tingkat lanjutan.

Kegiatan Diklat Berjenjang yang diselenggarakan oleh Himpaudi bertujuan untuk meningkatkan profesionalisme guru PAUD dan membantu tumbuh kembang anak usia dini secara optimal. Selain untuk meningkatkan kualitas mengajar guru PAUD, kegiatan Diklat Berjenjang juga bertujuan untuk merekomendasi guru TK yang belum berkualifikasi PAUD untuk mengikuti kualifikasi S1 PAUD. Adapun pokok kegiatan yang harus dilakukan oleh pengurus Himpaudi dalam kegiatan Diklat Berjenjang yaitu (1) meningkatkan profesionalisme guru PAUD; (2) mendorong agar pendidik PAUD dapat melanjutkan studi ke jenjang pendidikan yang lebih tinggi; (3) menyampaikan informasi beasiswa atau bantuan sejenisnya, jika ada pengumuman terkait hal tersebut; (4) mendorong agar terpenuhiya kesejahteraan pendidik PAUD melalui peningkatan dana Insentif yang mereka ikuti pada uji kompetensi, sertifikasi, dan lain sebagainya serta kegiatan konsultasi terkait PAUD.

Pada dasarnya pembiayaan Diklat Berjenjang yang diselenggarakan oleh Himpaudi menjadi kewenangan dan otonomi daerah masing-masing. Biaya kegiatan Diklat Berjenjang juga diupayakan dengan mendapat beberapa bantuan, seperti dana block grand PPTK PAUDNI, swadaya peserta dari dana intensif Dinas setempat, dari dana CSR, bantuan sosial (Bansos), hibah APBN dan APBD, serta dana dari peserta Diklat Berjenjang itu sendiri. Biaya yang dikeluarkan oleh peserta diklat tersebut tergantung pada jenjang diklat yang diikuti. Pada diklat tingkat dasar peserta harus membayar dengan biaya Rp 350.000,00 pada diklat tingkat lanjutan peserta harus membayar dengan biaya Rp 45000.000,00 - Rp 600.000,00 sedangkan pada diklat tingkat mahir biaya yang harus dikeluarkan lebih dari kedua diklat sebelumnya.

Stuktur organisasi Himpaudi Kecamatan Aikmel tersusun berdasarkan tugas masing-masing, terdapat ketua yang memimpin kepala-kepala PAUD se kecamatan Aikmel. Kepanitiaan kegiatan diklat Himpaudi di suatu wilayah tergantung pada kondisi daerah tempat pelaksanaan diklat tersebut. Penentuannya tergantung pada keadaan, situasi dan kondisi dari daerah tersebut.

Proses kegiatan Diklat Berjenjang yang diselenggarakan oleh Himpaudi Kecamatan Aikmel melalui 4 tahapan, yaitu tahap persiapan kegiatan Diklat 
Berjenjang, tahap pelaksanaan kegiatan Diklat Berjenjang, tahap pasca Diklat Berjenjang yaitu pembuatan tugas mandiri, dan tahap kelulusan. Proses Diklat Berjenjang yang diselenggarakan oleh Himpaudi Kecamatan Aikmel mulai dari persiapan Diklat Berjenjang yaitu menyusun dan membahas desain diklat, rapat koordinasi dengan instansi terkait yaitu Himpaudi di wilayah tersebut dan sekolahng melaksanakan diklat dibawah naungan dinas setempat. Menetapan kepanitiaan diklat, rapat koordinasi, sosialisasi pemanggilan peserta, penyusunan surat-surat dan lain sebagainya. Sarana dan prasarana yang harus disiapkan dalam kegiatan diklat juga harus diperhatikan, agar proses kegiatan Diklat Berjenjang dapat berjalan dengan maksimal tanpa ada hambatan yang berarti.

Adapun sarana yang disiapkan yaitu: (a) media dan bahan belajar yang terdiri dari modul/diktat/ handout, lembar bacaan, lembar peraga (transparan), lembar tugas, format instrument dan lembar evaluasi. Media dan bahan belajar tersebut digunakan saat pre-tes, proses, dan post-tes; (b)sarana pembelajaran yang terdiri dari meja dan kursi, papan tulis/whiteboard dan spidol, kertas dinding, OHP/LCD/ laptop, alat tulis peserta, alat tulis panitia dan alat tulis fasilitator.

Sedangkan prasarana yang disiapkan adalah: (a) ruang belajar/ ruang diskusi; (b) lokasi praktek pembelajaran PAUD; (c) asrama; (d) ruang makan; (e) toilet; (f) tempat ibadah; dan (g) ruang sekretariat panitia dan sarana olahraga Pelaksanaan kegiatan Diklat Berjenjang dilakukan melalui 3 tahapan, yaitu Diklat Tingkat Dasar, Diklat Tingkat Lanjutan, dan Diklat Tingkat Mahir. Masing-masing dari diklat tersebut akan ditentukan kelulusannya dengan membuat tugas mandiri. Jika peserta diklat menuntut ilmu program PAUD Strata 1 (S1), apabila telah memiliki 3 sertifikat Diklat Berjenjang, maka akan ada pengurangan Sistem Kredit Semester (SKS) yang harus ditempuh peserta tersebut. Jumlah SKS tersebut tergantung kebijakan masing-masing tempat belajar peserta tersebut. Pasca diklat yaitu pembuatan tugas mandiri yang merupakan tindak lanjut dan menjadi bagian yang tidak terpisahkan dari keseluruhan proses pelaksanaan Diklat Berjenjang. Peserta diklat wajib menyelesaikan tugas mandiri sesuai dengan pedoman diklat.

Penentuan keberhasilan dalam menyelesaikan tugas mandiri ditetapkan berdasarkan proses penilaian yang dilakukan secara komprehensif, objektif, terukur, dan dapat dipertanggung jawabkan. Penilaian terhadap peserta diklat dilakukan melalui prosedur yang tepat, utuh dan selaras dengan materi ajar yag diberikan. 
Penilaian dilakukan untuk mengukur kemampuan yang dimiliki dan diaktualisasikan melalui pemecahan masalah atau kasus yang terjadi di lembaga PAUD (tempat peserta diklat melaksanakn tugas mandiri).

Adapun tujuan dari tugas mandiri ini memperdalam pengetahuan yang didapat pada saat diklat. Mengaplikasikan pengetahuan, sikap, dan keterampilan yang diperoleh dari Diklat Berjenjang. Pelaksanaan diklat dilakukan dengan dua kegiatan utama, yaitu kegiatan diklat yang terstruktur (tatap muka dan penugasan terstruktur) dan kegiatan pasca diklat yaitu pelatihan yang dilakukan dengan membuat tugas mandiri. Pada kegiatan diklat terstruktur (tatap muka dan penugasan terstruktur) mengacu pada penjelasan perencanaan diklat, sedangkan kegiatan pasca diklat yaitu membuat tugas mandiri dilakukan oleh peserta diklat di lembaga PAUD dimana peserta diklat tersebut mengabdi. Proses pelaksanaan tugas mandiri dibawah bimbingan fasilitator yaitu tim yang ditunjuk oleh Himpaudi Kabupaten/kota selaku training provider serta dibantu oleh pemerintah daerah setempat dan tim panitia pelaksana untuk mengawal pelaksanaan kegiatan diklat dan pengawasan oleh kepala sekolah tempat peserta diklat tersebut mengabdi.

Terdapat 4 komponen utama yang dipersyaratkan Permendiknas No. 16 Tahun 2007 dan Permendiknas No. 58 Tahun 2009 yang harus diupayakan dapat terangkum dalam Diklat Berjenjang tersebut yaitu kompetensi pedagogik, kepribadian, sosial, dan profesional. Pengawasan pada kegiatan Diklat Berjenjang yang diselengarakan oleh Himpaudi Kecamatan Aikmel bertujuan agar kegiatan diklat dapat berjalan dengan lancar dan maksimal guna menghindari atau meminimalisir terjadinya kendala dalam kegiatan Diklat. Pengawasan kegiatan diklat dilakukan oleh tim fasilitator atau kendali mutu yaitu tim yang ditunjuk oleh Himpaudi Kabupaten Lombok Timur dan Dinas Pendidikan untuk mengawasi pelaksanaan kegiatan Diklat. Fasilitator dan narasumber diklat dapat berasal dari unsur birokat, akademisi profesional, praktisi dan anggota masyarakat yang memenuhi syarat yaitu (1) kualifikasi pendidikan minimal S1; (2) memiliki kompetensi dalam bidang PAUD; (3) menguasai materi Diklat; (4) menguasai metode dan strategi pembelajaran orang dewasa; (5) mampu menyediakan dan menyajikan rencana pelaksanaan pembelajaran (RPP) dan evaluasinya; (6) mampu berkomunikasi dengan baik; (7) direkomendasikan oleh lembaga atau instansi 
tempat ia bertugas; (8) diutamakan bagi yang memiliki sertifikat TOT sesuai dengan jenis program diklat; dan (9) mampu mengoperasikan IT.

Pengawasan kegiatan diklat tidak hanya dilakukan oleh tim fasilitator atau kendali mutu yaitu tim yang ditunjuk oleh Himpaudi Kabupaten Lombok Timur dan Dinas pendidikan saja namun juga seluruh pengurus dan panitia Himpaudi yang terlibat dalam kegiatan Diklat Berjenjang tersebut. Pada kegiatan pasca diklat yang dilakukan dengan membuat tugas mandiri, kegiatan pengawasan dilakukan oleh kepala sekolah tempat peserta diklat tersebut mengabdi, namun juga tidak lepas dari bimbingan fasilitator Himpaudi.

Evaluasi terhadap peserta untuk mengetahui tingkat kemampuan dan keberhasilan peserta dalam memahami materi diklat. Bentuk evaluasi peserta antara lain: pre test, tanya jawab, pengamatan selama proses pembelajaran, skor nilai tugas yang diberikan, dan post test. Evaluasi pasca pelatihan dilakukan melalui penilaian terhadap dokumen laporan yang disampaikan oleh peserta setelah melaksanakan tugas mandiri selama 25 hari efektif di lembaga PAUD masing- masing dengan fokus utama yaitu: (1) Diklat Tingkat Dasar: memahami tugas dan kewenangan dalam membantu guru dan guru pendamping; (2) Diklat Tingkat Lanjutan: Memahami dan mampu melakukan perencanaan, pelaksanaan dan penilaian pembelajaran; dan (3) Diklat Tingkat Mahir: Memahami dan mampu melakukan perencanaan, pelaksanaan dan penilaian pembelajaran yang lebih komprehensif.

Peserta harus membuat laporan tugas mandiri selambat- lambatnnya 30 hari efektif setelah mengikuti Diklat Berjenjang. Evaluasi terhadap fasilitator dilakukan untuk mengetahui kemampuan dalam membelajarkan, membimbing, memfasilitasi dan melatih substansi materi pada peserta Diklat, serta unjuk kerja fasilitator dengan didasarkan indikator sebagai berikut: (a) penguasaan materi; (b) penguasaan kelas; (c) sistematika penyajian; (d) kemampuan menyajikan materi; (e) ketepatan waktu; (f) penggunaan madia pembelajaran; (g) menguasai metode pembelajaran; (h) sikap dan perilaku; (i) pemberian motivasi; (j) cara menjawab pertanyaan; (k) penggunaan bahasa; (l) pencapaian tujuan pembelajaran; (m) kerapian berpakaian; dan (n) kerjasama antar fasilitator, peserta dan panitia. Evaluasi program Penyelengaraan diklat mencakup: (a) akomodasi; (b) pelayanan kesekretariatan; (c) ruang belajar; (d) sarana prasarana; (e) lingkungan/suasana belajar; Alat Tulis Kantor (ATK) peserta dan panitia diklat; dan (g) pelayanan kesehatan. 
Kegiatan diklat diharapkan dapat menambah wawasan dan pengetahuan guru PAUD. Guru yang mengikuti Diklat Berjenjang akan lebih mengerti pendidikan apa yang perlu diterapkan pada anak usia dini. Banyak guru PAUD yang belum memahami metode apa yang harus diterapkan pada anak usia dini, banyak guru PAUD yang beranggapan mendidik anak usia dini hanya cukup dengan mengajarkan membaca, menulis, dan berhitung tanpa mengetahui karakter alami dan psikis dari anak tersebut. Setelah menyelesai Diklat Berjenjang yang diselenggarakan oleh Himpaudi Kecamatan Aikmel, maka peserta diklat akan mendapatkan sertifikat kompetensi dan secara melekat memiliki kewenangan sesuai dengan kompetensi tersebut.

\section{PEMBAHASAN}

Saat ini banyak guru PAUD yang belum memahami metode apa yang tepat untuk diterapkan pada anak usia dini, untuk itu perlu adanya suatu wadah untuk mengampung aspirasinya dan tempat berkonsultasi terkait kendala-kendala yang dihadapi guru PAUD. Himpaudi Kecamatan Aikmel yaitu suatu wadah yang menampung berbagai urusan dan kegiatan PAUD di wilayah Kecamatan Aikmel Lombok Timur. Salah satu kegiatannya yaitu penyelenggaraan Diklat Berjenjang bagi guru PAUD dalam upaya meningkatkan pengetahuan dan kualitas kinerjanya. Hal tersebut sesuai dengan pendapat Soetjipto dan Kosasi (1994:46) "guru mendidik peserta didik hendaknya tidak hanya mengutamakan pengetahuan perkembangan intelektualnya saja, tetapi juga harus memperhatikan perkembangan seluruh pribadi peserta didik, baik jasmani, rohani, dan yang lainnya sesuai dengan hakikat pendidikan”. Jadi seorang guru PAUD tidak hanya mengutamakan pengetahuannya saja tanpa memikirkan perkembangan peserta didiknya, untuk itu perlu mengikuti Diklat Berjenjang agar terjadi keseimbangan antara pengetahuan guru PAUD dan metode apa yang harus diterapkan pada anak usia dini.

Diklat Berjenjang yang dilaksanakan oleh Himpaudi Kecamatan Aikmelr yaitu Diklat Tingkat Dasar, Diklat Tingkat Lanjutan, dan Diklat Tingkat Mahir. Pada masing-masing diklat tersebut akan dinyatakan kelulusannya dengan menyelesai tugas mandiri. Jika peserta tersebut sekolah lagi dan mengambil jurusan PAUD Strata 1 (S1) di perguruan tinggi yang bekerjasama dengan direktorat PPTK PAUDNI sebagai pemilik regulator program Diklat Berjenjang, maka akan ada 
pengurangan SKS yang harus ditempuh peserta diklat tersebut. Hal tersebut dapat dilakukan pada peserta Diklat Berjenjang yang memiliki 3 sertivikat Diklat Berjenjang Himpaudi yaitu baik mulai jenjang Diklat Tingkat Dasar, Diklat Tingkat Lanjutan, Maupun Diklat Tingkat Mahir. Jumlah SKS tersebut tergantung kebijakan masing-masing perguruan tinggi dimana peserta diklat tersebut belajar.

Hal demikian sesuai dengan pendapat Martoyo (2000:88) "Untuk memungkinkan sinkronnya dengan kepentingan organisasi, maka pihak departemen personalia dapat mengatur pengembangan karier, misalnya mengadakan programprogram latihan dan kursus-kursus pengembangan karier". Jadi untuk mengatur pengembangan pegawai yang dalam konteks ini yaitu guru PAUD, Himpaudi Kecamatan Aikmel melakukan program-program yang dapat meningkatkan kualitas dan profesionalisme kinerja seorang guru yaitu dengan melaksanakan program Diklat Berjenjang. Kegiatan Diklat Berjenjang yang diselengga- rakan oleh Himpaudi Kecamatan Aikmel bertujuan untuk meningkatkan mutu kompetensi pendidik PAUD dalam mengajar, mengetahui perkembang- an anak usia dini, membantu anak usia dini dalam pertumbuhan dan perkembangannya secara optimal, mensosialisasikan pentingnya PAUD yang berkualitas kepada semua lapisan masyarakat, menyiapkan generasi yang berkualitas untuk membangun bangsa dan negara, serta mengupayakan kesejahteraan para pendidik PAUD.

Seorang guru dalam konteks ini yaitu seorang yang berperan dalam tumbuh kembang anak usia dini. Tujuan adanya kegiatan Diklat Berjenjang yang diselenggarakan oleh Himpaudi Kecamatan Aikmel agar kesejahteraan guru PAUD lebih terjamin dan guru dapat meningkatkan kualitas mendidiknya sehingga tidak salah dalam mendidik anak usia dini, karena didikan yang benar sesuai masa dan usianya akan menghasilkan anak yang pintar, cerdas, dan berakhlak sesuai masanya. Selain itu guru PAUD di Indonesia, khususnya Kecamatan Aikmel harus mensosialisasikan pentingnya PAUD yang berkualitas kepada semua lapisan masyarakat untuk membangun bangsa dan generasi baru yang lebih baik.

Hal tersebut sesuai dengan pendapat Hasibuan (2005:10) menjelaskan "MSDM adalah suatu bidang manajemen khusus mempelajari hubungan dan peranan manusia dalam suatu perusahaan. Unsur MSDM adalah manusia yang merupakan tenaga kerja pada perusahaan”. Jadi manusia yang merupakan tenaga kerja pada perusahaan dalam konteks ini yaitu seorang guru PAUD di sekolah 
tempat guru tersebut mengabdi. Guru yang profesional di bidangnya akan melahirkan sekolah yang unggul dan berkualitas. Sehingga peran guru sangat berpengaruh dalam meningkatan mutu kualitas anak didiknya dan sekolah tempat guru tersebut mengabdi.

Robinson (dalam Marzuki, 1993:12) mendefinisikan pelatihan sebagai pengajaran atau pemberian pengalaman kepada seseorang untuk mengembangkan tingkah laku (pengetahuan, skill, sikap) agar mencapai sesuatu yang diinginkan. Seperti halnya yang diungkapkan Yoto (1997:25) bahwa penataran dan pelatihan adalah serangkaian kegiatan pendidikan yang mengutamakan perubahan pengetahuan, keterampilan, dan peningkatan sikap seorang pegawai dalam melaksanakan tugasnya. Jadi diharapkan kegiatan diklat dapat merubah dan mengembangkan tingkah laku seseorang dalam segi pengetahuan, skill dan sikap dalam melaksanakan tugasnya sebagai seorang pendidik.

Hal demikian sesuai dengan tujuan diklat yang diselenggarakan oleh Himpuadi Kecamatan Aikmel yaitu meningkatkan profesionalisme guru PAUD dan membantu tumbuh kembang anak usia dini secara optimal. Selain untuk meningkatkan kualitas mengajar guru PAUD, pendapat lain juga dipaparkan oleh Johariah, S.Pd, selaku ketua panitia Kecamatan Aikmel yang menjelaskan bahwa Diklat Berjenjang juga bertujuan untuk merekomendasi guru TK yang belum berkualifikasi PAUD untuk mengikuti kualifikasi S1 PAUD.

Pernyataan tersebut sesuai dengan pendapat Martoyo (2000:87) "pengembangan karier terdapat dua macam yakni pengembangan karier secara individual dan pengembangan karier secara organisasional. Pengembangan karier secara individual adalah setiap guru harus siap mengembangkan dirinya dalam rangka menjalan- kan kariernya lebih lanjut". Jadi untuk menjadi seorang guru yang berkualitas dan profesional dibidangnya, seorang guru harus meningkatkan pengetahuannya baik secara individu yaitu dengan kesadaran dirinya untuk meningkatkan kemampuan dan potensinya sebagai seorang guru PAUD, maupun secara organisasi yaitu dengan mengikuti kegitan diklat dalam upaya meningkat- kan kualitas mengajarnya. Karena guru yang berkualitas akan menghasilkan anak didik yang berkualitas pula.

Tugas pokok yang harus dilakukan oleh pengurus Himpaudi Kecamatan Aikmel dalam kegiatan Diklat Berjenjang yaitu (1) meningkatkan profesionalisme 
guru PAUD; (2) mendorong agar pendidik PAUD dapat melanjutkan studi ke jenjang pendidikan yang lebih tinggi; (3) menyampaikan informasi beasiswa atau bantuan sejenisnya, jika ada pengumuman terkait hal tersebut; (4) mendorong agar terpenuhiya kesejahteraan Pendidik PAUD melalui peningkatan dana Insentif yang mereka ikuti pada uji kompetensi, sertifikasi, dan lain sebagainya; (5) serta kegiatan konsultasi terkait PAUD. Dengan tugas pokok tersebut diharapkan guru yang mengikuti Diklat Berjenjang dapat meningkatkan kualitas mengajar dan taraf pendidikannya yang lebih tinggi, serta lebih sejahtera dari sebelumnya.

Pernyataan diatas sesuai dengan pendapat Soetjipto dan Kosasi (1994:42) "Peningkatan profesionalisme guru dapat dilakukan melalui penataran, lokakarya, pendidikan lanjutan, pendidikan dalam jabatan, studi perbandingan dan berbagai kegiatan akademik lainnya”. Jadi, kegiatan pembinaan profesi tidak hanya terbatas pada pendidikan prajabatan atau pendidikan lanjutan diperguruan tinggi saja, melainkan dapat juga dilakukan setelah yang bersangkutan lulus dari pendidikan prajabatan, ataupun sedang melaksana- kan jabatan. Dengan kegiatan tersebut diharapkan dapat meningkatkan profesionalisme dalam bekerja dan meningkatkan taraf pendidikannya ke jenjang yang lebih tinggi. Stuktur organisasi Himpaudi Kecamatan Aikmel tersusun berdasarkan tugas masing-masing, terdapat ketua, sekretaris bendahara. Kepanitiaan kegiatan diklat Himpaudi di suatu wilayah tergantung pada kondisi daerah tempat pelaksanaan diklat tersebut.

Pernyataan di atas sesuai dengan pendapat Hasibuan (2005:22) menjelaskan "Pengorganisa- sian adalah kegiatan mengorganisasi semua karyawan dengan menetapkan pembagian kerja, hubungan kerja, delegasi wewenang, integrasi, dan koordinasi dalam bagan organisasi (organization chart). Organisasi hanya merupakan alat untuk mencapai tujuan. Dengan organisasi yang baik akan membantu terwujudnya tujuan secara efektif'. Jadi struktur organisasi di Himpaudi Kecamatan Aikmel dibentuk berdasarkan tugas masing-masing, sesuai jabatan yang telah ditetapkan guna sebagai alat untuk mencapai tujuan yang telah ditetapkan. Kepanitiaan kegiatan diklat Himpaudi tergantung pada kondisi di daerah tempat pelaksanaan diklat tersebut. Proses kegiatan Diklat Berjenjang yang diselenggarakan oleh Himpaudi Kecamatan Aikmel dilakukan melalui 4 tahapan, yaitu tahap persiapan kegiatan Diklat Berjenjang, tahap pelaksanaan kegiatan Diklat Berjenjang, tahap pasca Diklat Berjenjang yaitu pembuatan tugas mandiri, dan tahap kelulusan. 
Kegiatan Diklat Berjenjang dimulai dengan mempersiapkan atau merencanakan halhal yang berhubungan dengan Diklat Berjenjang seperti mempersiapkan lokasi kegiatan, materi diklat pada jenjang apa yang akan di diklatkan, dan lain sebagainya, kemudian pelaksanaan diklat sesuai dengan apa yang direncanakan, selanjutkan peserta diklat menger- jakan tugas mandiri yang dibimbing oleh kepala sekolah tempat guru tersebut mengabdi dan pemateri Himpaudi, lalu evaluasi dengan menyusun laporan diklat yang akan dikirim ke PPTK PAUDNI yang lokasinya di Jakarta. Sirkula (dalam Mangkunegara, 2003:50) mengemukakan bahwa pelatihan (training) adalah suatu proses pendidikan jangka pendek yang mempergunakan prosedur sistematis dan terorganisasi...". Pendapat tersebut sesuai dengan proses diklat yaitu mulai persiapan hingga evaluasi, agar kegiatan diklat dapat berjalan dengan sistematis dan maksimal sesuai tujuan diklat yang telah ditetapkan. Sedangkan menurut Marzuki (1993:5): Dictionary of education, training atau pelatihan diartikan sebagai suatu pengajaran tertentu yang tujuannya telah ditentukan secara jelas, biasanya dapat diragakan yang menghendaki peserta didik mempraktekkannya, dengan bimbingan pendidik dan penilaian terhadap perbaikan unjuk kerja peserta didik. Training atau pelatihan diartikan pula sebagai suatu proses membantu orang lain dalam memperoleh skill dan pengetahuan. Pendapat tersebut sesuai dengan kegiatan tugas mandiri yang dilakukan oleh guru yang mengikuti Diklat Berjenjang yang diselenggarakan oleh Himpaudi Kecamatan Aikmel. Kegiatan tersebut dilakukan dalam upaya mempraktekan ilmu pengetahuannya yang diperoleh guru selama mengikuti Diklat Berjenjang kedalam lingkungan sekolah tempat guru tersebut mengabdi. Dengan kegiatan tersebut guru akan lebih mengetahui hal- hal apa saja yang harus diterapkan pada anak usia dini di sekolahnya. Pengawasan pada kegiatan Diklat Berjenjang yang diselengarakan oleh Himpaudi Jawa Timur bertujuan agar kegiatan diklat dapat berjalan dengan lancar dan maksimal guna menghindari atau meminimalisir terjadinya kendala dalam kegiatan diklat. Pada dasarnya pengawasan kegiatan diklat dilakukan oleh tim fasilitator atau kendali mutu yaitu tim yang ditunjuk oleh Himpaudi Lombok Timur dan Dinas pendidikan untuk mengawasi pelaksanaan kegiatan diklat, namun pengawasan juga dilakukan oleh ketua atau penanggung jawab di wilayah masingmasing, yang jelas setiap bidang pasti ada koordinatornya. Akan tetapi pengawasan tidak hanya dilakukan oleh ketua atau koordinator saja melainkan juga seluruh 
pengurus Himpaudi yang diatur dalam SOP, jika tidak sesuai baru ada informasi tindaklanjut atau pemberitahuan. Pada kegiatan pasca diklat yang dilakukan dengan membuat tugas mandiri, kegiatan pengawasan dilakukan oleh kepala sekolah tempat peserta diklat tersebut mengabdi, namun juga tidak lepas dari bimbingan fasilitator Himpaudi. Keberhasilan pelaksanaan Diklat Berjenjang yang diselenggarakan oleh Himpaudi dapat diketahui dengan melakukan evaluasi terkait kegiatan tersebut. Adapun evaluasi yang dilakukan meliputi evaluasi terhadap peserta, evaluasi terhadap fasilitator, dan evaluasi program Penyelengaraan yang dijelaskan sebagai berikut.

Pernyataan tersebut sesuai dengan pendapat Sonhadji (2013:187) Pengawasan adalah proses untuk menjaga agar tercapainya tujuan organisasi secara efisien. Proses ini menyangkut perumusan standar, membandingkan kinerja yang diukur terhadap standar yang dirumuskan, serta menguatkan keberhasilan dan mengkoreksi kegagalan. Jadi pengawasan perlu dilakukan untuk mengetahui keberhasilan dan kendala organisasi dalam mencapai tujuan yang telah ditetapkan.

Menurut Ulfatin (2013:33) “evaluasi formatif diarahkan untuk perbaikan profesinalisme guru...”. jadi evaluasi dilakukan oleh Himpaudi Kecamatan Aikmel pada peserta, fasilitator,dan program Penyelengaraan Diklat Berjenjang untuk memperbaiki profesionalisme guru. Kegitaan diklat diharapkan dapat menambah wawasan dan pengetahuan guru PAUD. Guru yang mengikuti Diklat Berjenjang akan lebih mengerti pendidikan apa yang perlu diterapkan pada anak usia dini. pendapat Ibu Suwarti, S.Pd, AUD selaku Sekretaris Himpaudi, beliau menjelaskan bahwa kegeitan Diklat Berjenjang yang diikutinya berisi materi-materi PAUD di bangku kuliah selama 8 semester. Banyak guru PAUD yang belum memahami metode apa yang harus diterapkan pada anak usia dini, banyak guru PAUD yang beranggapan mendidik anak usia dini hanya cukup dengan mengajarkan membaca, menulis, dan berhitung tanpa mengetahui karakter alami dan psikis dari anak tersebut.

Menurut Bafadal (2008:44) menyatakan, “ peningkatan profesionalisme guru dapat diartikan sebagai upaya membantu guru yang belum matang menjadi matang, yang tidak mampu mengelola sendiri menjadi mampu mengelola sendiri, yang belum memenuhi kualifikasi menjadi memenuhi kualifikasi, yang belum terakreditasi menjadi terakreditasi”. Pendapat tersebut sesuai dengan hasil yang diperoleh guru 
PAUD setelah mengikuti Diklat Berjenjang yang diselenggarakan oleh Himpaudi Kecamatan Aikmel, sebelumnya guru tersebut belum memahami pendidikan dan metode apa yang tepat untuk diterapkan pada anak usia dini dalam pembelajaran, namun setelah mengikuti Diklat Berjenjang guru tersebut menjadi paham dengan pendidikan dan metode yang harus diterapkan pada anak usia dini, agar anak tersebut dapat tumbuh dengan maksimal sesuatu tahap perkembangannya.

\section{E. KESIMPULAN DAN SARAN}

\section{Kesimpulan}

Diklat Berjenjang yaitu Diklat Tingkat Dasar, Diklat Tingkat Lanjutan, Dan Diklat Tingkat Mahir. Adapun penjadwalan, syarat, dan tugas pokok telah ditetapkan oleh pengurus Himpaudi. Pembiayaan Diklat Berjenjang menjadi kewenangan dan otonomi daerah masing-masing.

Kepanitiaan kegiatan Diklat Berjenjang Himpaudi di suatu wilayah tergantung pada kondisi daerah tempat pelaksanaan diklat tersebut. Pelaksanaan diklat dilakukan dengan dua kegiatan utama, yaitu kegiatan diklat yang terstruktur dan kegiatan pasca diklat.Pengawasan kegiatan diklat dilakukan oleh tim fasilitator atau kendali mutu.

Evaluasi yang dilakukan terhadap peserta, fasilitator, dan program Penyelengaraan. Adapun hasil dari kegiatan Diklat Berjenjang yaitu (a) banyak guru PAUD yang belum memahami metode untuk diterapkan pada anak usia dini; (b) setelah mengikuti Diklat Berjenjang, guru PAUD lebih memahami metode untu diterapkan oleh anak usia dini.Sedangkan hasil penelitian kegiatan Diklat Berjenjang Himpaudi Kecamatan Aikmel yaitu (a) manajemen kegiatan diklat mulai perencanaan hingga evaluasi sesuai dengan kajian pustaka terkait penelitian ini; (b) materi dan program Diklat Berjenjang yang diberikan oleh Himpaudi Kecamatan Aikmel sesuai dengan permasalahan dan kebutuhan yang dialami oleh guru PAUD; (c) kegiatan Diklat Berjenjang dapat menambah wawasan dan pengetahuan guru PAUD.

\section{Saran}

Bagi Ketua Himpaudi Kecamatan Aikmel, hendaknya membuat peraturan dan kebijakan bagi guru PAUD yang berpendidikan SMP di wilayah terpencil jika mengikuti kegiatan Diklat Berjenjang. Sedangkan bagi guru PAUD, hendaknya tidak 
Ittihad | Manajemen Diklat Berjenjang Tingkat Dasar Untuk.Meningkatkan Kompetensi Guru Paud (Kegiatan Swadaya Bekerjasama Dengan SKB dan Himpaudi Kecamatan Aikmel)

hanya mengikuti Diklat Tingkat Dasar saja, melainkan harus melanjutkan pada tingkat berikutnya. Minimal mengikuti hingga Diklat Tingkat Lanjutan, guna dapat memperoleh keterampilan yang memadai dalam upaya meningkatkan kompetensi mengajarnya.

\section{DAFTAR PUSTAKA}

Akademik dan Kompetensi Guru. Kementerian pendidikan dan kebudayaan Republik Indonesia direktorat jenderal PAUD (online) (www.paudni.kemdikbud.go.id), akses tanggal 5 Maret 2015.

Bafadal, I. 2008. Peningkatan Profesionalisme Guru Sekolah Dasar. Jakarta: Bumi Aksara.

Hasibuan, M.S.P.2005. Manajemen Sumber Daya Manusia. Jakarta: PT Bumi Aksara

Mangkunegara, A. A. A. P. 2003. Perencanaan dan Pengembangan Sumber Daya Manusia. Bandung: PT Refika Aditama.

Martoyo, S. 2000. Manajemen Sumber Daya Manusia. Yogyakarta: BPFE.

Marzuki, M. S. 1993. Strategi dan Model Pelatihan. Malang: Departemen Pendidikan dan Kebudayaan Institut Keguruan dan Ilmu Pendidikan Malang Bagian Proyek Operasi dan perawatan Fasilitas Proyek IKIP Malang.

Pendidikan dan Kebudayaan Institut Keguruan dna Ilmu Pendidikan Malang Proyek Operasi dan Perawatan Fasilitas. Peraturan Pemerintah Nomor 16 Tahun 2007 tentang Standar Kualifikasi

Simamora, H. 1997. Manajemen Sumber Daya Manusia. Yogyakarta: STIE YKPN.

Soetjipto \& Kosasi. 1994. Proyek Pembinaan dan Peningkatan Mutu Tenaga Sonhadji, A. 2013. Manusia, Teknologi, dan Pendidikan Menuju Peradaban Baru. Malang: Penerbit Universitas Negeri Malang.

Ulfatin, N. 2013. Metode Penelitian Kualitatif di Bidang Pendidikan: Teori dan Aplikasinya. Malang: Bayumedia Publishing.

Yoto. 1997. Manajemen Pendidikan dan Pelatihan. Malang: Departemen 